\title{
THE IMPACTS OF APPLYING NATIONAL PAYMENT GATEWAY IN THE INDONESIAN PAYMENT SYSTEM AS THE ECONOMIC DEMOCRACY IMPLEMENTATION
}

\author{
Hassanain Haykal ${ }^{1}$ \\ ${ }^{1}$ Faculty of Law, Maranatha Christian University \\ Email: hassanain.haykal@gmail.com
}

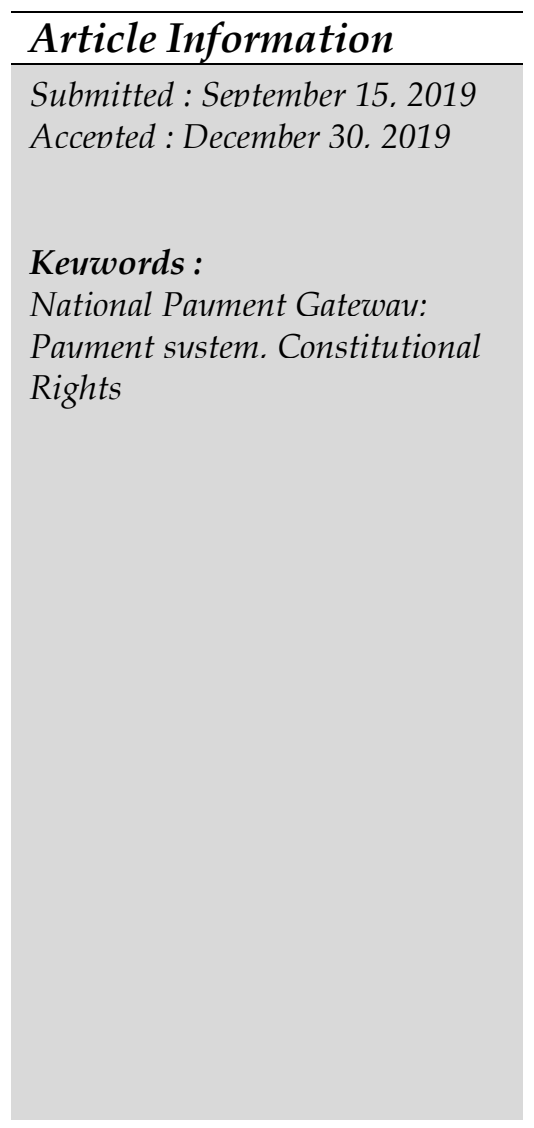

\begin{abstract}
The National Payment Gateway (NPG) is developed to make the payment infrastructure more efficient, reliable, and secure for both local and international transactions. This is in line with the state's efforts to implement the constitutional rights of citizens contained in Article 33 of the 1945 Constitution. State efforts in the NPG urged to be done to support the fulfillment of the constitutional rights of citizens in the economic field. Therefore, this study aims to determine the impact of applying NPG in the Indonesian payment system as a form of fulfilling the constitutional rights. This study uses a type of legal normative research in the form of legal behavior products. The results show that the application of NPG could be the basis for processing mass payment transactions through the integration of all payment channels and domestic processing which has not been carried out efficiently. Therefore, the NPG rules and mechanisms are determined for all domestic payment transactions and instruments from domestic issuers, with all the processes carried out locally. This was conducted to broaden people's acceptance of non-cash transactions and a way of making it become an integral part of Bank Indonesia's efforts in facilitating non-cash movements within the country. NPG is also part of the fulfillment of the constitutional rights of the community, in which the community is given the ease and efficiency in making transactions as a form of economic democracy with the principle of togetherness, equitable efficiency, sustainability, by maintaining a balance of progress and national economic unity.
\end{abstract}

\section{Introduction}

The payment system is vital to the economy of any country in terms of development. It facilitates the transfer of funds between businesses and consumers. Hence, the need for payment systems with minimal barriers becomes increasingly urgent. Also, updates of payment system should be based on its role and position which should not affect the country's economy. Thus, all incorporated element in it should synergize as a single unit, which allows for a stronger payment system. According to Titiheruw \& Atje, the core participants of any national payment system are the commercial banks and nonbank financial institutions (NBFIs) (Ira S. Titiheruw and Raymond Atje 2009:5).

Also, the Bank for International Settlements explains that the development of a safe and efficient national payment system plays a vital role in the monetary policy, financial stability, and overall economic development of the country's central bank (Bank for International Settlements, 2006: 1). This is also central to the effective implementation of 
monetary policy using money market transactions to influence the overall financial and economic activities. In addition, developments in the payment system have tremendous effects on the speed and certainty in the circulation of monetary balances which also affects the overall use of money. Furthermore, by linking financial institutions together, it helps in efficiently settling payment obligations and transferring of monetary claims, and the national payment system becomes the most appropriate channel through which financial risk can be transmitted across these institutions and the general markets.

In addition, the National payment systems help in minimizing the systemic risks with the financial institutions. In line with this, Ali and Al-Jabri stated in a research that the financial stability of any institution mostly depends on the capacity and effectiveness of payment systems to control the potential systemic credit risks (Saqlb Ali and Ali AlJabri, 2011:2). Some of these risks manifest when the failure of one participant in fulfilling the required obligations in the payment system causes another failure, thereby resulting in a chain capable of affecting the completion of transactions and the national financial system. The series of events could be made worse with a high degree of interrelation between various payment systems involving different countries, which could cause the rapid spread of any potential failure.

Considering the various aspects of the risks in other systems, the focus of the Central Bank in several countries, including Indonesia, is the development and implementation of the national payment system. Thus, the Central Bank in Indonesia is trying build a national payment system with interconnection and capable of being used globally. These is based on the fact that existing platforms have not been interconnected with each other, hence, have not been able to provide a system capable of serving one another. The simplest illustration is the long queue usually found in areas such as malls with ATMs and lined Electronic Data Capture (EDC) machines used by cashiers at supermarkets in Indonesia.

Some of problems also encountered in Indonesia come up with the challenges of switching domestic transaction, which has been in existence for more than 20 years, and still limited to ATM services. However, other services such as cross-issuing and debit card transactions acquirer (off-us), where the card is issued in Indonesia, are held by Indonesians and used to purchase goods/services in the country, their transactions are processed overseas. This fragmentation, in turn, creates inefficiencies in the national payment system. Therefore, in an effort to solve these challenges, Bank Indonesia continues to develop national payment systems, which are implemented through the National Payment Gateway (NPG). This effort is in accordance with the research conducted by Giri which explains that the Central Banks are with the oversight power to constantly maintain and improve the payment systems in the area of safety and efficiency for the use of all parties (Pralhad Giri, 2013:117).

The development of NPG is a mandate of citizenship rights as Article 33 of the 1945 Constitution states that the national economy is based on economic democracy with the principles of togetherness, fair efficiency, sustainable, environmentally friendly, independent, and by maintaining a balance of progress and national economic unity. Furthermore specifically, the development and implementation of NPG, is in line with the mandate given by the Act to Bank Indonesia as the authority saddled with 
the responsibility of achieving a safe, smooth, and efficient national payment system. The simple NPG is an electronic system for processing various payment transactions through several instruments such as ATM/debit cards, electronic money, and credit cards. With the use of the NPG, the public can effectively process domestic non-cash transactions from any bank. Also, Gulati \& Srivastava explain the basic advantages using NPG, which include: decreased number of intermediaries and reduced costs (Ved Prakash Gulati and Shilpa Srivastava, 2007:104).

The Governor of Indonesia Central Bank, Mr. Agus Martowardojo, on December 21, 2016, signed a Memorandum of Understanding (MoU) concerning the interconnectivity and interoperability between debit cards and electronic money. This MoU was signed by four banks as acquirers, which represent $75 \%$ of all domestic debit transactions, namely BRI, Bank Mandiri, BNI, and BCA, including four principals for the switching operations, namely Electronic Payment Services, Alto Network, Rintis Sejahtera, and Jalin. The MoU represents a concrete form of the industry's commitment to support the implementation of the NPG plan as prepared by Bank Indonesia.

Furthermore, signing the MoU shows a solid movement to realize NPG in Indonesia infrastructure. This involves interoperable and interconnected facilitates, as well as the processing of domestic transactions using various instruments, ranging from ATM/debit cards, electronic money, EDC, credit cards, agents, and other payment gateways. NPG also expands public access to non-cash transactions and revenues, while promoting the National Non-Cash Movement (NNCM) and financial inclusion in public areas. In addition, NPG has the capacity to expand the number issuers of domestic/ national payment system, instruments and services, and encourage innovation. Finally, the implementation of NPG is expected to develop the resilience, independence, and competitiveness of the national payment system.

\section{Research Methods}

The research method with a normative juridical approach, prioritizes library research and its implementation in practice. Research specifications are descriptive. The research phase is carried out through library research, collecting secondary data in the form of primary, secondary, and field research materials to obtain primary data as a support.

\section{Research Result and Discussion}

\section{A. National Payment Gateway and Economic Democracy According to 1945 Constitution}

Based on the results of this study, it is evident that Bank Indonesia introduced NPG as a system which integrates various payment channels to facilitate electronic transactions. Therefore with interconnection between switching and interoperability, NPG provides safe, quality and efficient electronic transactions for all Indonesian. The results also show that the rules and mechanism of NPG are determined for all domestic payment transactions and all payment instruments are issued by domestic issuers, and need to be processed locally as well. This is to broaden 
people's acceptance of non-cash payment transactions with the use of retail payment instruments, which is an integral part of Bank Indonesia's efforts to facilitate noncash movements in the country.

Also, the application of national payment gateway in Indonesia allows all transaction operations to be carried out locally. The switching institutions are managed by national companies to enhance the smooth implementation of NPG between switching agencies. Therefore, the payment channel can be used for all payment instruments belonging to different banks that collaborate with NPG, a process known as interoperability. In addition, its charges are cheaper and users have no need to pay fees abroad. It also increases the income of national companies and boosts the country's foreign exchange. Furthermore, the data processing is carried out by the company itself, hence safeguarding the Indonesian data. The constitutional basis related to customer data in NPG is based on the Law of the Republic of Indonesia Number 10 of 1998 concerning Amendment to Law Number 7 of 1992 on Banking, which explains that Banks are required to keep information regarding the depositing customer and its deposits.

The implementation of a national payment gateway is in line with Article 33 of the 1945 Constitution which stated that the economy is based on economic democracy carried out with the principles of togetherness, efficiency, sustainability, environmental friendliness, independence, as well as by maintaining a balance of progress and unity. Therefore, it is clear that the country seeks to create an interoperable, interconnected payment system capable of processing transactions that include authorization, clearing, and domestic settlement. It is expected to increase consumer protection by securing each transaction, ensuring the availability/ integrity of the national payment system, support the effectiveness of monetary policy transmission, intermediation efficiency, and financial system resilience.

Another constitutional right in the national payment gateway is the right to privacy, which was implicitly contained in Article 28 paragraph (1) of the 1945 Constitution. According to it, everyone has the right to protection of personal, family, honor, dignity, and property under their authority. In addition, they are entitled to a sense of security and protection from threats to carry out their fundamental human right. In the context of the national payment gateway, the state seeks to guarantee various privacy methods for the protection of its citizens.

Another constitutional right contained in the application of NPG is the populist economic concept built by a state-owned bank. According to Article 33, paragraph 2 of the 1945 Constitution, the state controls the branches of production and the livelihoods of many people, through the development of state-owned enterprises. Conversely, the state exercised constitutional rights to ensure it achieves its goals o. Therefore, NPG has a mutually beneficial relationship with people's economy (Pancasila) actors, and the state.

The payment system is related to payment gateways carried out online in all e-business transactions related to the banking system. It is a special purpose system to handle payment, its authorization between clients and merchants, as well as directs transfers. According to Ailya Izhar et al., a payment gateway is connected 
to all customers, merchants, and banks through the internet, to facilitate the speed, reliability and security of all online transactions (Ailya Izhar et al., 2011: 85). In addition, Anuja et al. reported that the payment gateway allows secure transactions (Anuja Pande, A.B. Deshmukh, and M.D. Tambakhe, 2014:2069).

According to Krantee and Hetal, through payment gateways, users and merchants both could transact easily. And e-payment is an easy and reliable way to do the shopping and other transactions (Krantee Jamdaade and Hetal Champaneri, 2015:72). Anushree and ZaidIqbal also explained that the payment gateway could be provided by a bank to its customers, however, it could also be provided by a specialized financial service provider as a separate service, such as a payment service provider (Anushree Banerjee and ZaidIqbal 2017:1). Therefore, it is obvious that the payment gateway facilitates transactions through transferring information between payment portals such as websites or cell phones. Thus, it connects all aspects including customers, traders, and banks through fast, reliable and secure internet in every electronic financial transaction.

\section{B. The Use of Technology for Economic Purposes and Global Economy Development}

The use of technology for economic purposes leads to growth and development which improves performance and develops the global economy. Also, information and communication technology (ICT) increases competitive advantage and contributes to creating new jobs (Ahmad Alavi, 2015: 9). However, ICT acceptance is an important factor which needs serious examination by each organization. Therefore, in this study, researchers tested various models using the ICT for the payment system. Also, the use of the unified theory of acceptance and entrepreneurial to offer a comparison of a modified conceptual coherent model in terms of user involvement and intention to use as two additional factors regarding payment system user behavior ( Atae Rezaei Aghdam et al., 2017:497).

Also, the payment systems are the core group of strategic information systems, which contribute to the economic development, especially in developing countries, and form the foundation for the financial sector, as well as the national information infrastructure development (Tanai Khiaonarong, 2000:59). This has become a major concern for central banks in developing countries in improving their national financial infrastructure and increase their potential of becoming a major financial center. Hence, the payment system developed by the central bank is known as NPG. This is very important for the economic and financial activities at both the national and international levels. Hence, the orderly function of NPG is very important considering the fact that most economic transactions are carried out and completed through the national system. Also, the Central Bank is the main infrastructure for managing monetary policy, the implementation of which requires efficient processing and completion of operations (Saqlb Ali and Ali Al-Jabri, 2011:2).

In the context of the comparison, Saqlb Ali and Ali Al-Jabri explain in their study that the development of payment systems in the United States has been influenced by diverse factors. First, there are many financial intermediaries which provide 
payment, clearing, and settlement services. Second, the legal framework governing payment activities as well as the regulatory structure for financial institutions in the United States is complex. Third, various payment instruments and settlement mechanisms are available to free payment obligations between financial institutions and their customers. These payment instruments vary in their characteristics, such as costs, technology, convenience, availability of funds and finality, as well as orientation towards consumer, commercial, and interbank transactions (Saqlb Ali and Ali Al-Jabri, 2011:6).

The research conducted by Saqlb Ali and Ali Al-Jabri also revealed the concept of the Bank of England acting as a settlement agent which provides the highest, risk-free ways to relinquish payment obligations between parties with the provision of settlement accounts for the banking sector. These accounts have been kept in real-time gross settlement (RTGS) Bank, which provides posting real-time with finality and cannot be withdrawn from the debit, while the participant's account is credited. The RTGS system settles for all major sterling interbank payment systems or schemes in the UK. It also helps the two most important systems that clean the home automatic payment system (CHAPS) and that in the settlement of UK securities (CREST) (Saqlb Ali and Ali Al-Jabri, 2011:6-7).

In addition, the research of Saqlb Ali \& Ali Al-Jabri explains that building societies and credit union in Australia helped in the provision of payment services. The Australian Payment Clearing Association (APCA), which is the main body in the industry, is responsible for the daily management of the payment clearing system. However, the system has changed significantly in recent years. This was in response to technological change and the comprehensive reform program embarked upon in the industry. The main objective of the reform process to date has been to improve system security and integrity, and the introduction of Australia's real-time gross settlement (RTGS) system in June 1998 has become an integral part of the reform (Saqlb Ali and Ali Al-Jabri, 2011:8).

Based on the findings on the website of Australian Central Bank, the Reserve Bank Information and Transfer System (RITS) is an Australian high-value payment system used by banks and other approved institutions to settle their payment obligations under the RTGS . Such payments are final, irrevocable settlement and entered directly into the RITS. Some netted payment obligations are also settled in RITS as part of a batch. Payments processed through the low-value clearing system are currently settled in RITS on a net suspension basis once a day. However, the Australian Central Bank is in the process of providing the infrastructure that will enable more timely settlement of payments (Saqlb Ali and Ali Al-Jabri, 2011:8).

In terms of benefits, the research conducted by Monika Verma \& Pankaj Jagtap stated that payment gateway is the access point of online Banking network, where all transactions are processed (Monika Verma and Pankai Jagtap, 2017:1547). The payment gateway acts as a bridge between the user's website and the financial institution processing the transactions. The payment gateway route authenticates each payment made. Also, most users trust this platform more than the existing local online payment gateway considering the fact that it is more secured. In addition, 
people gravitate towards electronic payment system with many advantages as well as meeting their needs with the provision of security privacy.

Furthermore, the development of national payment system was implemented by Nepal Rastra Bank (NRB) where it is an integral part of the country's financial sector, vital for its soundness, and monetary policy implementation and capital market development. Also, the NRB is committed to the safety and efficiency of Nepal's National Payments System (NPS) (Nepal Rastra Bank n.d.:4). The National Payments System (NPS) concept has been accepted by a group of institutions based on a set of instruments and procedures used to facilitate the circulation of money locally and at international level. The NRB adopted a strategic approach to payment system reform in Nepal, thereby, making it safe, efficient and such which is capable of contributing effectively country's economical growth and financial stability.

Theoretical comparisons of various national payment systems revealed that the application of payment gates oriented to the national flow system is an important initiative from the Central Bank. This is reinforced by Sumanjeet's opinion which explains that virtually all interested parties, which include academicians, government, the business community, and financial service providers, are exploring various types of electronic payment systems and accepting payments through digital currencies (Sumanjeet, 2009:14). Thus, this could be linked to the reason why Bank Indonesia implemented NPG for the development of a safe and efficient national payment system which impacts on the monetary policy, financial stability, and the overall economic development interests of the central bank. Therefore, the central bank monitors its developments by assessing the impact on money demand, the effect of monetary policy transactions, the efficiency, and stability of financial markets related to the crisis.

\section{Technology as The Calatyst in Accelerating The Growth of The National Payment Gateway}

Furthermore, series of developments occur when there is a payment gateway trend indicating that more Indonesians are conducting financial transactions electronically through banks ATMs, internet, and SMS-bankings (Veronica S. Moertini et al., 2011:16). Based on a report, the number of ATM transactions was 3.5 to 4 million, out of a total of 5 million transactions a day in a large bank in Indonesia. Also at other banks, ATM transactions increase 32\% per year. Based on this, banks in Indonesia believe that ATM transactions will continue to increase in the coming years thereby adding more ATMs throughout the country. However, web technology has also been used widely in recent years. Also, the internet transactions in Indonesia have also increased rapidly, up to $87 \%$ in one quarter, as well as SMS and cellular banking transactions. Thus, it is safe to say that conducting transactions electronically has become a necessity and way of life for the Indonesia people (Veronica S. Moertini et al., 2011:16).

Therefore, the payment system landscape in Indonesia continues to grow and technology has been the catalyst in accelerating its development. However, the condition of this system ecosystem is relatively complex and tends to be 
fragmented. This fragmentation is as a result of the absence of interconnection has made its infrastructure inefficient. Hence, NPG was developed to make payment infrastructure more efficient, reliable, and secure. Also, the institutional rules and mechanisms in the NPG are the guide for the interconnection or interoperability of the domestic retail payment system industry.

In addition, the development of NPG in Indonesia aims to improve the systems' efficiency and security related to national interests, including the needs as well as the ways of life of the people. The NPG is expected to overcome the challenges in the Indonesian payment system, namely: (1) shortcomings in the efficiency of payment system infrastructure caused by limited interconnectivity and interoperability; (2) security risks resulting from data management in bilateral transactions between principals; and (3) domestic debit transactions, some of which are still processed internationally. However, the reasons why Indonesia needs to have a payment gateway, include: (1) To create national payment system sovereignty thereby allowing the country to exercise control over domestic transactions, specifically, domestic Card-Based Payment Instruments (CBPI); (2) To reduce the dependence on foreign principals; (3) To save the country's foreign exchange considering the fact that the domestic transaction fees are obtained and enjoyed by national principals; (4) To increase the efficiency in national payments considering the fact that there will be sharing between parties involved in the payment system; (5) To improve the efficiency of banking transactions; and (6) To facilitate business transaction processes in Indonesia, both online and offline, with guaranteed security, since it is supported by various trusted financial institutions.

The road map for the implementation of NPG is carried out in stages, which is to be completed in 2021. The major task achieved in 2017 was the interconnection between domestic switching operators, the implementation of ATM and debit interoperability, and electronic money interconnection. Then, the implementation of Electronic Bills and Invoices Presentation and Payment (EBIPP) as well as the expansion of internet, mobile and e-commerce services were achieved in 2018. The implementation of domestic credit cards in 2019, and the processing of domestic transactions for international principals to be achieved in 2021. According to Makarim \& Taira, Bank Indonesia aims to expand the acceptance of the NPG system through national branding. This will include rules related to domestic logos and processing. Also, the party connected to NPG must (i) include the logo in the payment instrument they issue or the payment channel they provide; and (ii) have a means of payment that shows a national logo (Makarim and Taira S., 2017:2). However, Bank Indonesia Regulation number 19/8/PBI/2017 do not state whether it applies to newly issued cards or includes existing cards.

Bank Indonesia Regulation (BIR) No. 19/8/PBI/2017 guiding the National Payment Gateway mentioned the parties in the GPN which are the Standard, Switching, and Services institutions. Also, the connected parties are the Issuer, Acquirer, Payment Gateway Operator, and other parties determined by Bank Indonesia. For more details, here is a non-cash payment process in NPG: 


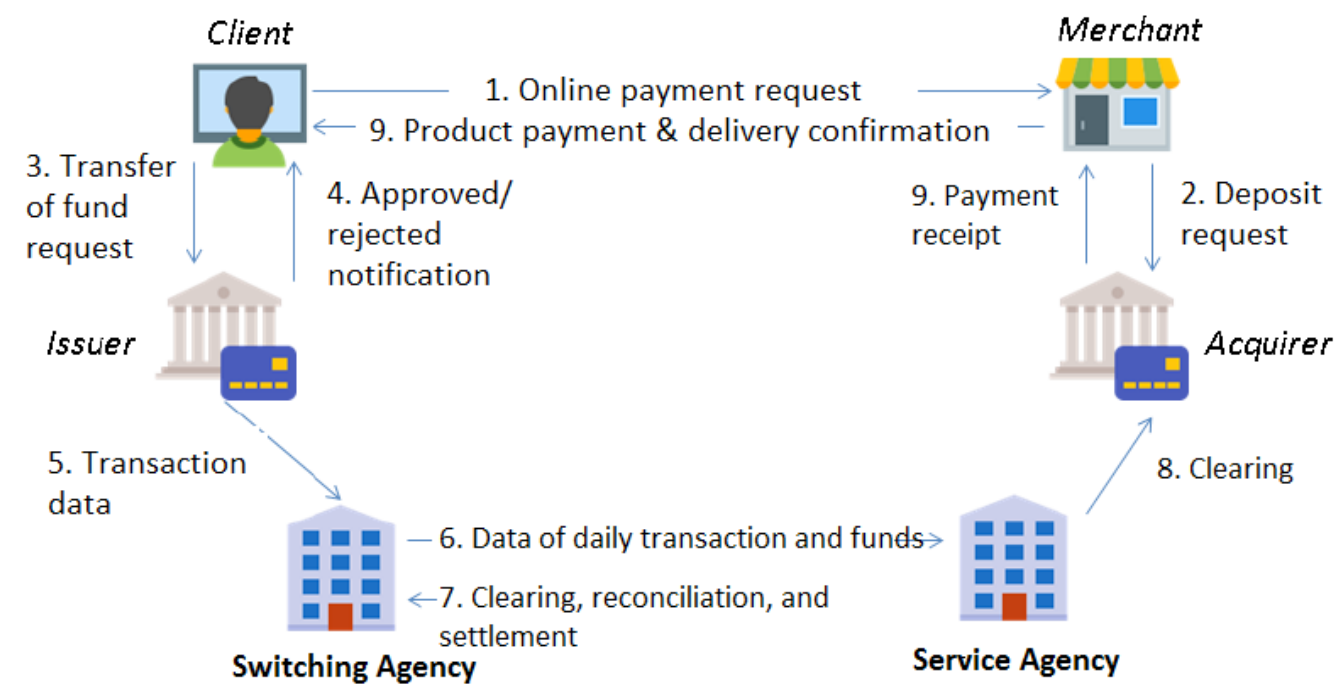

Figure 1.

Non-Cash Payment Process in NPG

Source: Bank Indonesia, 2019.

The NPG is the framework for the non-cash payment system in Indonesia. The implementation of the non-cash payment system policy was a solution to the inefficiencies inhibiting the acceptance of non-cash transactions, well as solutions to the development of the digital economy. And more clearly, the parties connected with GPN are the commercial and Islamic commercial banks, as well as other institutions. Also, Rural Bank (BPR) and Islamic people's finance banks can be connected to NPG through commercial or Islamic commercial banks.

Table 1. National Payment Operator and Infrastructure

\begin{tabular}{|l|c|c|c|}
\hline \multicolumn{1}{|c|}{ Operator } & Bank & Acquirer & Principal \\
\hline Credit Card & 65 & 18 & 7 \\
\hline Debit Card & 24 & 13 & 5 \\
\hline Infrastructure & ATM & Merchant & EDC Machine \\
\hline & 103,953 & 652,201 & $1,106,632$ \\
\hline
\end{tabular}

Source: Artajasa, (2017)

The Standards Institutions are solely in charge of compiling and managing national payment technology standards set by Bank Indonesia, which must be obeyed by all industries These include NSICCS for ATM/Debit transactions, and SAM Multi Applet for Electronic Money. And currently, the Standards Institution is managed by the Indonesian Payment System Association (IPSA). Hence, the Standards Institution is directed in the form of legal entities with professional, competent and independent management.

The Switching Institutions are in charge of conducting data processing of domestic transactions safely and efficiently. At the inception of NPG, Bank Indonesia 
has established four domestic switching operators namely Nusantara Interfaith Payment, Electronic Payment Artajasa, Rintis Sejahtera, and Alto Network.

The Services Institutions have four main tasks, namely: (1) maintaining transaction security by ensuring end-to-end data encryption; (2) efficient reconciliation-clearing-settlement; (3) handling transaction disputes ensuring consumer protection; and (4) encourage the expansion of acceptances of non-cash instruments. They are formed and jointly owned by the GPN Switching Institution and subsidiaries of major industry players such as BRI, BNI, Bank Mandiri, and BCA.

Through NPG, cost incurred by customers for non-cash transactions is lower compared with the normal interbank transfer fees and domestic retail payments. NPG creates interconnection of network infrastructure for payment transactions data using one ATM/debit card, also known as switching, with other networks in Indonesia. Interconnection switching also helps to achieve interoperability between two or more payment channels. Also, the payment instrument infrastructure can be used jointly by the card-issuing banks. And a reduction in transaction costs also occurs since the retail payment transaction process using cards in Indonesia must go through GPN, and no longer dependent on foreign principals.

Table 2. Comparison of Price Schemes before and After NPG Implementation in Indonesia

\begin{tabular}{|c|c|c|c|}
\hline $\begin{array}{l}\text { Types of Price } \\
\text { Schemes }\end{array}$ & Before NPG & After NPG & Information \\
\hline \multicolumn{3}{|c|}{$\begin{array}{l}\text { On us (transactions are carried out by the same issuer } \\
\text { and acquirer) }\end{array}$} & \multirow{10}{*}{$\begin{array}{l}\text { MDR is charged } \\
\text { to the merchant/ } \\
\text { trader (as currently } \\
\text { applicable) } \\
\text { This number/price } \\
\text { will be evaluated } \\
\text { periodically and } \\
\text { can be reviewed if } \\
\text { necessary }\end{array}$} \\
\hline Regular Merchants & $\begin{array}{l}\text { MDR range from } \\
\text { up to } 3.5 \% \%\end{array}$ & $\begin{array}{l}\text { MDR } \\
0.15 \mathrm{MDR}\end{array}$ & \\
\hline $\begin{array}{l}\text { Special Merchant } \\
\text { Education }\end{array}$ & $\begin{array}{l}\text { Ranges up to } \\
3.25 \%\end{array}$ & MDR $0.15 \%$ & \\
\hline $\begin{array}{l}\text { Special Merchant } \\
\text { Merchants }\end{array}$ & $\begin{array}{l}\text { MDR range up } \\
\text { to } 3.25 \%\end{array}$ & MDR 0.15\% & \\
\hline $\begin{array}{l}\text { Special Merchants } \\
\text { G2P, P2G,donations }\end{array}$ & $\begin{array}{l}\text { MDR range up } \\
\text { to } 3.25 \%\end{array}$ & MDR 0\% & \\
\hline \multicolumn{3}{|c|}{$\begin{array}{l}\text { Off us (transactions are carried out by different } \\
\text { publishers and acquirers ) }\end{array}$} & \\
\hline Regular Merchants & $\begin{array}{l}\text { MDR range up to } \\
3.5 \%\end{array}$ & MDR 1\% & \\
\hline $\begin{array}{l}\text { Education Special } \\
\text { Merchants }\end{array}$ & $\begin{array}{l}\text { MDR range up to } \\
3.25 \%\end{array}$ & MDR $0.75 \%$ & \\
\hline $\begin{array}{l}\text { SPBU Special } \\
\text { Merchants }\end{array}$ & $\begin{array}{l}\text { MDR range from } \\
\text { up to } 3.25 \%\end{array}$ & MDR $0.5 \%$ & \\
\hline $\begin{array}{l}\text { Special Merchants } \\
\text { G2P, P2G,Donations }\end{array}$ & $\begin{array}{l}\text { MDR range up to } \\
3.25 \%\end{array}$ & MDR 0\% & \\
\hline
\end{tabular}

Source: Bank Indonesia, 2018. 
With this set of policies, positive impacts are expected which could encourage the sharing of infrastructure. Therefore, this increases the utilization of ATM/ EDC terminals and the excess is relocated to deficient areas. Then, infrastructure investment costs are diverted back to financing/loan facility which will ultimately have a positive impact on the country's economic growth. Also, NPG reduces the complexity of connections from previously bilateral between parties, to a more centralized form. In addition, it is useful for the community, allowing the members to transact from any bank, using any payment instruments and channels. Another benefit of NPG is that it helps to build a sort of national efficient payment system created from a more competitive pricing scheme. Whereas NPG is constitutionally in line with Article 4 of the Law of the Republic of Indonesia Number 10 of 1998 concerning Amendment to Law Number 7 of 1992 concerning Banking, the purpose of Indonesian banking is to support the implementation of national development in order to increase equity, economic growth and national stability in the direction of increasing the welfare of many people.

\section{Conclusion}

The NPG infrastructure is developed to make payments more efficient, reliable, and secure. Also, the rules and mechanisms are employed by various institutions which allow interconnection or interoperability of transactions within and outside the country. In addition, the NPG initiative is delivered through the active involvement of the payment systems industry in a coordinated manner thereby connecting the domestic infrastructure to the global networks. NPG could also be the basis for processing mass payment transactions through the integration of all domestic payment and processing channels, which have not been able to be carried out efficiently. Therefore, the rules and mechanism of NPG is determined for all domestic transactions and payment instruments from domestic issuers, which is processed domestically. The aim is to expand public acceptance of non-cash payment transactions and make it become an integral part of Bank Indonesia's efforts in facilitating non-cash movements within the country. However, the implementation of NPG still needs to prioritize national interests, encourage the application of the principles of prudence, risk management, and consumer protection, based on the international standards and practices.

In the context of constitutional rights, the implementation of the national payment gateway is contained in Article 33 of the 1945 Constitution which stated that the national economy is based on the principles of togetherness, efficiency, sustainability, environmental friendliness, independence, as well as by maintaining a balance of progress and unity. Another constitutional right in the national payment gateway is the privacy, as stated in Article 28 paragraph (1) of the 1945 Constitution of the Republic of Indonesia, where every person has the right to personal, family, honor, dignity, and property under their control. In addition, they are entitled to a sense of security and protection from threats to carry out their fundamental human rights. In the context of the national payment gateway, the state seeks to guarantee various privacy methods for the protection of its citizens. 


\section{BIBLIOGRAPHY:}

\section{Working Papers:}

Bank for International Settlements. (2006). General Guidance for National Payment System Development. Switzerland: Press \& Communication BIS.

Makarim, and Taira S. (2017). Bank Indonesia's National Payment Gateway Introduced.

Titiheruw, Ira S, and Raymond Atje. (2009). Asian Development Bank Institute Working Paper Series Payment System in Indonesia: Recent Developments and Policy Issues. Tokyo.

\section{Journals:}

Aghdam, Atae Rezaei et al. (2017). "Performance Assessment of Payment Gateways in Banking, a Case of Electronic Banking Services in Tehran, Iran." International Journal on Computer Science and Engineering 9(8): 496-505.

Alavi, Ahmad. (2015). "Review of Technology Acceptance and Use Behavior." Kuwait Chapter of Arabian Journal of Business and Management Review 4(7): 9-14.

Ali, Saqlb, and Ali Al-Jabri. (2011). “Oman's National Payment Systems and Their Compliance with International Standards and Practices." Journal of Internet Banking and Commerce 16(3). http://www.icommercecentral.com/open-access/omansnational-payment-systems-and-their-compliance-with-international-standardsand-practices.php?aid=38286.

Banerjee, Anushree, and ZaidIqbal. (2017). "Payment Gateways with Special Reference to Paytm." Journal of Exclusive Management Science 6(11).

Giri, Pralhad. (2013). "Payment and Settlement System Development in Nepal : Hurdles and Way Out." Economic Journal of Development Issues 15 \& 16(1-2): 116-27.

Gulati, Ved Prakash, and Shilpa Srivastava. (2007). “The Empowered Internet Payment Gateway." Computer Society of India: 98-107. http://www.iceg.net/2007/ books/2/10_342_2.pdf.

Izhar, Ailya et al. (2011). “Designing and Implementation of Electronic Payment Gateway for Developing Countries." Journal of Theoretical and Applied Information Technology 26(2).

Jamdaade, Krantee, and Hetal Champaneri. (2015). “A Review: Secured Electronic Payment Gateway." International Journal of Technology Enhancement and Emerging Engineering Research 3(6).

Khiaonarong, Tanai. (2000). "Electronic Payment Systems Development in Thailand." International Journal of Information Management 20(1): 59-72.

Moertini, Veronica S., Asdi a. Athuri, Hery M. Kemit, and Nico Saputro. (2011). "The Development of Electronic Payment System for Universities in Indonesia: On Resolving Key Success Factors." International Journal of Computer Science $\mathcal{E}$ Information Technology (IJCSIT) 3(2): 16-33. http:/ / arxiv.org/abs/1105.0153.

Nepal Rastra Bank. Nepal Payment System Development Strategy. Nepal. 
Pande, Anuja, A B Deshmukh, and M D Tambakhe. (2014). “E-Payment Gateway Model.” International Journal of Computer Science and Information Technologies 5(2): 2569-73.

Sumanjeet. (2009). "Emergence of Payment Systems in the Age of Electronic Commerce: The State of Art." Global Journal of International Business Research 2(2): 17-36.

Verma, Monika, and Pankaj Jagtap. (2017). “Comparative Study of Different Payment Gateway." International Journal of Scientific E Engineering Research 8(6): 1547-50.

\section{Legal Documents:}

The 1945 Constitution of the State of the Republic of Indonesia $4^{\text {th }}$ Amendment

Law of the Republic of Indonesia Number 10 of 1998 on Amendment to Law Number 7 of 1992 on Changes in Indonesian Banking Goals 